Indra Andili Ngelo \& Syenshie Virgini Wetik

Pengaruh Pendidikan Kesehatan Metode Jigsaw Terhadap Tingkat Pengetahuan Konsep Diri Remaja

\title{
Pengaruh Pendidikan Kesehatan Metode Jigsaw Terhadap Tingkat Pengetahuan Konsep Diri Remaja
}

\author{
Indra Andili Ngelo', Syenshie Virgini Wetik² \\ ${ }^{1,2}$ Fakultas Keperawatan Universitas Katolik De La Salle Manado
}

Korespondensi penulis: sywetik@gmail.com

\begin{abstract}
Abstrak
Banyaknya permasalahan yang terjadi pada remaja saat ini, berdampak pada konsep diri remaja. Remaja yang memiliki konsep diri kurang baik akan mengalami bingung peran pada tahap perkembangan selanjutnya. Hal ini ditandai dengan tidak mengenal identitas dirinya sendiri, tidak menyukai bagian tubuhnya, merasa bingung dan bimbang, menarik diri, gampang dipengaruhi, serta memiliki pergaulan yang negatif. Tujuan penelitian ini untuk mengetahui pengaruh pendidikan kesehatan metode jigsaw terhadap tingkat pengetahuan konsep diri pada remaja. Penelitian ini menggunakan desain penelitian quasi eksperimetal. Populasi pada penelitian ini berjumlah 75 orang siswa/i dengan jumlah sampel 60 responden. Pemilihan sample menggunakan teknik purposive sampling. Hasil uji man whitney pre-post kelompok kontrol memperoleh mean rank 19.40 dan post-test kelompok perlakuan memperoleh nilai mean rank 41.60 dengan nilai $p$-value $00.00(p<0,05)$. Sehingga disimpulkan bahwa adanya pengaruh yang signifikan antara pengaruh pendidikan kesehatan metode jigsaw terhadap tingkat pengetahuan konsep diri remaja di SMK Baramuli Airmadidi.
\end{abstract}

Kata Kunci: metode jigsaw; pengetahuan remaja; konsep diri

\section{PENDAHULUAN}

Fase remaja adalah salah satu fase yang harus dilewati setiap individu dalam masa pertumbuhan dan perkembangan. Menurut Hurlock dalam Malahayanti (2010) menyebutkan bahwa fase ini adalah peralihan masa kanak-kanak menuju dewasa, individu sehingga mencapai kematangan mental, emosional, sosial, fisik. Pada fase ini remaja mencapai karakteristik berbeda atara satu remaja dengan yang lain (Zola, 2017). Sedangkan menurut Anisa (2016) menyebutkan bahwa pada fase ini terjadi perubahan fisik, psikis dan sosial.

Meningkatnya populasi pertumbuhan remaja berdampak juga berbagai permasalahan remaja. Permasalahan tersebut dapat bersifat individual dan massal, meliputi tawuran antar sekolah dan lingkungan tempat tinggal, merokok, penggunaan NAPZA dan alkohol, perilaku seks bebas serta perilaku yang disertai dengan masalah emosional yang lazim muncul pada masa remaja. Depkes \& IDAI (2013) mengemukakan masalah yang terjadi pada remaja seringkali disebabkan oleh emosi pada remaja yang berada pada posisi puncaknya sehingga remaja tidak mampu memecahkan masalah dan dapat menyebabkan tindakan yang dilakukan menjadi diluar kontrol. Stuart (2013) menjelaskan lebih luas tentang permasalahan yang muncul pada remaja saat masa perkembangan. Permasalahan ini meliputi konflikkonflik yang terjadi pada citra tubuh, 
identitas diri, peran sosial, perilaku seksual dan kebebasan.

Salah satu satu upaya yang dilakukan untuk tercapainya perkembangan remaja yang optimal yaitu berupa peningkatan pengetahuan remaja yang didalamnya melibatkan remaja dan orang tua, terapi seni dan olahraga serta bimbingan kelompok. Imadiyanti dan Gusniarti (2013) menjelaskan lewat hasil penelitiannya bahwa kepedulian remaja terhadap sesama dapat meningkatkan pengetahuan dan kecerdasan emosional pada perkembangan remaja. Kim, Kim \& Ki, (2014). menjelaskan melalui terapi seni dalam bentuk kelompok/group pada remaja mampu memberikan dampak yang baik dalam peningkatan pengetahuan tentang konsep diri

Berdasarkan uraian diatas maka peneliti tertarik untuk meneliti tentang Pengaruh Pendidikan Kesehatan Metode Jigsaw terhadap Pengetahuan Konsep Diri Remaja di SMK Baramuli Airmadidi

\section{METODE}

Penelitian ini menggunakan desain penelitian kuasi eksperimental. Tujuannya adalah untuk meneliti pengaruh sebuah perlakuan terhadap sekelompok objek penelitian dengan menggunakan kelompok perbandingan (Suyanto, 2011).

Pengumpulan data pada penelitian ini dengan menggunakan kuesioner (pre-post test) dengan metode intervensi berupa pemberian pendidikan kesehatan dengan metode jigsaw. Pemilihan sampel menggunakan metode purposive sampling dengan jumlah 60 responden yang dibagi menjadi 2 kelompok yaitu 30 responden sebagai kelompok intervensi dengan metode jigsaw dan 30 reponden sebagai kelompok kontrol yang tidak diberi perlakuan apapun.

\section{HASIL}

Karakteristik responden dikelompokkan berdasarkan usia dan jenis kelamin. Pada penelitian ini sebagian responden berusia 15 tahun dengan jenis kelamin adalah perempuan.

Hasil Analisa Perbandingan Tingkat pengetahuan Kelompok Kontrol dan Kelompok Intervensi ditunjukkan pada tabel 1 dibawah ini:

Tabel.1 Hasil Analisa Perbandingan Tingkat Pengetahuan Remaja

\begin{tabular}{cllcl}
\hline No & Responden & n & $\begin{array}{c}\text { Mean } \\
\text { rank }\end{array}$ & $\begin{array}{c}\text { p- } \\
\text { value }\end{array}$ \\
\hline 1 & Kel. Kontrol & & & \\
\cline { 2 - 4 } & Pre-test & 30 & 13,11 & 0,894 \\
\cline { 2 - 3 } & Post-test & 30 & 14,96 & \\
\hline 2 & Kel.Intervensi & & \\
\cline { 2 - 3 } & Pre-test & 30 & 9,00 & 0.000 \\
\cline { 2 - 3 } & Post-test & 30 & 15,44 & \\
\hline \multicolumn{4}{c}{ tentang Konsep Diri pada Kelompok } \\
& Kontrol dan Kelompok Intervensi
\end{tabular}

Berdasarkan tabel diatas dapat dilihat bahwa $\mathrm{p}$-value pada pre post kelompok kontrol >0.05 dengan pvalue (0.894) dan pre-test post-test kelompok intervensi $<0.05$ dengan $\mathrm{p}$ value $(0.00)$ yang artinya Ha diterima dan Ho ditolak. Kesimpulannya ada perbedaan tingkat pengetahuan kelompok kontrol dan kelompok perlakuan

\section{PEMBAHASAN}

Kurangnya pengetahuan tentang konsep diri pada remaja dapat disebabkan oleh faktor internal maupun eksternal. Faktor internal misalnya kurangnya motivasi dari diri sendiri untuk mencari informasi tentang konsep diri, sedangkan faktor eksternal yaitu masih kurangnya pengetahuan yang dimiliki oleh 
keluarga dan pihak sekolah mengenai konsep diri sehingga belum mampu memberikan arahan dan bimbingan terhadap perkembangan tumbuh kembang remaja. Hal ini kemudian berdampak pada remaja tidak mengenali setiap proses perubahan yang terjadi dalam dirinya,

Pergaulan di lingkungan sosial juga sangat mempengaruhi pengetahuan konsep diri remaja, dimana banyak remaja yang mengalami bingung peran, menarik diri bahkan tidak dapat bertanggung jawab dengan proses perkembangan pada dirinya sendiri, sehingga yang terjadi kurangnya pengetahuan terhadap konsep diri pada remaja. Hal ini sejalan dengan teori yang dikemukan oleh Nola J. Pender yang didalamnya mendefinisikan hal ini sebagai pengaruh interpersonal dan situasional, lingkungan yang mengarah pada keadaan fisik dan interpersonal serta perilaku yang dapat berpengaruh pada tingkat pengetahuan remaja.

Metode jigsaw adalah metode pembelajaran yang dapat diterapkan pada kelompok remaja karena berbagai kelebihannya (Naomy Nurseri, 2015). Menurut Budiono (2011) untuk meningkatkan pengetahuan remaja salah satunya dengan mengunakan metode jigsaw. Metode ini merupakan media pembelajaran yang komperhensif bagi remaja karena memberikan kesempatan yang sangat luas serta melatih remaja untuk berani menyuarakan pendapat dan analisa sesuai apa yang menjadi landasan pikiran mereka. Sehingga dengan metode jigsaw ini diharapkan mampu memberikan pengaruh pada tingkat pengetahuan remaja tentang konsep diri mereka.

Faktor-faktor lain yang peneliti temukan yaitu pemilihan leader kelompok memiliki pengaruh yang sangat besar dari keberhailan metode jigsaw. Leader dipilih dengan kriteria memiliki daya tangkap yang baik sehingga anggota kelompok menjadi koperatif dan bersemangatndalam proses pemberian intervensi. Keunggulan lainnya yang peneliti temukan dari metode jigsaw yaitu metode ini mampu mengeksplorasi daya serap informasi dengan baik karena dianggap sebagai metode pembelajaran yang baru dan unik yang dilakukan dengan kelompokkelompok kecil sehingga membuat penyerapan materi menjadi jauh lebih efektif.

Pemberian media leaflet sebagai alat bantu untuk menjelaskan komponen informasi dalam kelompok serta adanya pendampingan dari peneliti dapat menciptakan suasana belajar yang baik. Hal ini juga sejalan dengan konsep teori yang dikemukakan oleh Nola J. Pender yaitu kondisi lingkungan internal dan eksternal yang baik dapat menjadi pengaruh yang besar dalam proses pembelajaran untuk mengenal baik buruknya diri dari individu tersebut.

Model pendidikan kesehatan dalam proses tersebut dapat menggambarkan interaksi manusia dengan lingkungan fisik dan interpersonalnya, yang meliputi perilaku manusia yang saling mempengaruhi. Temuan ini didukung oleh penelitian yang dilakukan oleh Victoria, dkk (2015) yang menyebutkan bahwa diperlukan kerjasama antara peneliti dan responden untuk dapat menciptakan situasi yang nyaman dan konsentrasi sehingga remaja mampu menyerap materi yang diberikan pada remaja.

Jadi, jika remaja mempunyai pengetahuan konsep diri yang baik 
Indra Andili Ngelo \& Syenshie Virgini Wetik

Pengaruh Pendidikan Kesehatan Metode Jigsaw Terhadap Tingkat Pengetahuan Konsep Diri Remaja

maka dalam remaja akan mampu melewati fase perkembangannya dengan optimal dan mampu melaksanankan tugas dan tanggung jawab dalam perannya sebagai seorang remaja. Melalui pemilihan media informasi maupun metode pembelajaran yang tepat maka akan mampu meningkatkan pengetahuan remaja baik di sekolah maupun di lingkungan keluarga

\section{KESIMPULAN}

Berdasarkan hasil penelitian ini maka peneliti menyimpulkan bahwa sebagian besar responden berusia 15 tahun dengan jenis kelamin adalah perempuan. Selain itu ditemukan bahwa ada pengaruh pendidikan kesehatan metode jigsaw terhadap tingkat pengetahuan konsep diri pada remaja. Metode jigsaw direkomendasikan untuk dapat digunakan dalam pemberian pendidikan kesehatan kepada remaja.

\section{DAFTAR PUSTAKA}

Abdul Rahman (2015). Psikologi sosial. PT Raja Grafindo Persada:Jakarta

Alligood, M. (2014). Pakar Teori Keperawatan dan Karya Mereka Edisi Indonesia Ke-8 Volume 1. Singapura: ELSEVIER.

Budiono (2011). Metodelogi Pendidikan. Surakarta: UNS Pers

Donsu. (2017). PSIKOLOGI KEPERAWATAN.

Yogyakarta: PUSTAKA BARU PRESS.

Effendi dan Makhfudli. (2009). Keperawatan Kesehatan Komunitas Teori dan Praktik dalam Keperawatan. Jakarta: Salemba Medika.

Hurlock, E.B (2011). Devolepmental
Psychology: A Lifepan Approach. (diterjemahkan oleh Istiwidyanti). Jakarta: Erlangga Gunasara

Ikatan Dokter Indonesia (IDAI). (2015). http://www.idai.or.id/artikel/u ncategorized/penelitian-

kualitas-hidup-anak-aspekpenting-yang-seringterlewatkan,

Ifdil. (2017). Hubungan body image dengan kepercayaan diri pada remaja. kesehatan pisikologi.

Jahja, Y. (2011). Psikologi Keperawatan. Jakarta: Penada Media Grup.

Jaya. (2015). Keperawatan Jiwa. Tangerang Selatan: BINARUPA AKSARA.

Natoatmodjo, S. (2009). Pendidikan Kesehatan Masyarakat. Jakarta: Rineka Cipta.

Nursalam \& Evendi (2009) Pendidikan dalam

Keperawatan. Jakarta:

Salemba Media

Nigsih, M., \& Mistina, H. (2018). Teori dan praktik berbagai metode pembelajaran. surakarta: percetakan persero CV.

Siswanto dkk. (2016). Metodologi Penelitian Kesehatan dan Kedokteran. Yogyakarta: Bursa Ilmu.

Soekidjo, N. (2014). Promosi Kesehatan Dan Perilaku Kesehatan. Jakarta: CV Budi Utama.

Susanto, A. (2018). Bimbingan Dan Konseling Di Sekolah Konsep,Teori dan Aplilasi. jakarta: Penademedia Groub.

Suyanto. (2011). Metodelogi Dan Penelitian Keperawatan. Yogyakarta: Haikhi.

Suyanto. (2011). Metodologi dan 
Indra Andili Ngelo \& Syenshie Virgini Wetik

Pengaruh Pendidikan Kesehatan Metode Jigsaw Terhadap Tingkat Pengetahuan Konsep Diri Remaja

Aplikasi Penelitian

Keperawatan. Yogyakarta:

Nuha Medika

Zola, dkk (2018). Profil Kepercayaan

Diri Remaja Serta Faktor-

Faktor Yang Mempengaruhi 